\title{
Mitä sivistysjärjestöt odottavat tutkimukselta
}

Yritän suhteellisen lyhyesti sivistysjärjestöjen osalta tulkita niitä tuntoja, joita ns. kentällä on aikuiskasvatustutkimusta kohtaan.

Aluksi haluaisin painottaa sitä itsestäänselvyyttä, että sivistysjärjestöt vapaan sivistystyön osana tarvitsevat varsin kipeästi aikuiskasvatustutkimusta - samoin kuin ns. kokeilutoimintaa ja akateemisiin perustutkintoihin sisältyviä tutkielmia. Luulen, että sivistysjärjestöissä ollaan erittäin huolestuneita viime vuosien kehityksestä, jolloin vapaaseen sivistystyöhön kohdistunut tutkimus on jäänyt entistä niukemmaksi. Lisähuoli sivistysjärjestöjen kohdalla syntyy siitä, että vaikka niiden toiminta on viimeisen kymmenen vuoden aikana kasvanut määrällisesti voimakkaastikin, niin sivistysjärjestöt ovat jatkuvasti tutkimukselle neitseellistä maaperää - poikkeuksena Aulis Alasen "'Sivistysjärjestöt valtion säätelyssä" -tutkimus. Tieteellisen tutkimuksen puuttuessa sivistysjärjestöjen toiminnassa joudutaankin liian usein turvautumaan hyvin sattumanvaraiseen oikeiden ratkaisujen hakemiseen tai vain ns. kokemuksen tuomaan näköalaan.

Miksi sitten järjestöllinen sivistystyö ei kiinnosta tutkimusta? Osasyynsä lienee sivistysjärjestöjen tietynlaisessa sisäänlämpiävyydessä, mutta myös sivistystyön lähtökohtien erilaisuudessa verrattuna kansalais- ja työväenopistoihin tai kansanopistoihin. Niin ikään opintotoiminnan lyhytkestoisuus aiheuttanee ongelmia pitkäjänteisen tutkimustyön järjestämiselle. Onneton seuraus nykytilanteesta on joka tapauksessa se, että sivistysjärjestöt joutuvat vuosittain omaa toimintaa arvioidessaan ja kehittäessään nojaamaan erittäin niukkoihin ja osittain puutteellisiinkin tilastotietoihin.

Mitä tulee yleisemmin aikuiskasvatustutkimuksen ja käytännön välisiin suhteisiin, allekirjoitan sen Aulis Alasen näkemyksen, että tieteellisen tutkimuksen ja aikuiskasvatuksen käytännön yhteisenä päämääränä on yhteiskunnallisen todellisuuden yhä syvempi ja totuudellisempi tiedostaminen. Eli tutkimuksen ainakin pitäisi näyttää suuntaa aikuiskasvatuksen kokonaisuudessa.
Pidän tärkeänä sitäkin, että aikuiskasvatustutkimuksen tulisi kyetä särkemään myyttejä - joita todella riittää jo aikuiskasvatuksenkin sisällä - puuttumaan näihin myytteihin ja asettaa kyseenalaisiksi ne monet käsitykset, uskomukset ja toimintamallit, jotka juuri tutkimuksen puuttuessa ovat käytännön aikuiskasvatustyössä vakiintuneet itsestäänselvyyksiksi. Aikuiskasvatustyön kehittämiseksi tarvitaan sekä teoreettisesti orientoitunutta että ns. suunnittelututkimusta. Joskin aikuiskasvatus on ns. käytännöllinen tieteenala, se on myös nuori tieteenala, jolloin perustutkimus ja teorian kehittäminen ovat sille erittäin tärkeitä alueita. Ja teoria palvellee sittenkin jossain vaiheessa käytännön työtä.

Esitän seuraavaksi joitakin käytännön tutkimustarpeita, jotka ovat varsin täsmentymättömiä, mutta koetaan sivistysjärjestöissä tärkeiksi tutkimuksen kohteiksi.

- osallistumis/motivaatiotutkimus sivistysjärjestöjen opintotoiminnasta, jolloin koko "oppimisen kulttuuri" tulisi laajemmin tarkastelun kohteeksi; osallistujien motiivien tutkiminen, miksi he osallistuvat, mitä osallistuminen vaikuttaa heidän elämäänsä, mitä tapahtuu opiskelun jälkeen.

- vertaileva osallistumistutkimus vapaan sivistystyön eri muotojen - ennen kaikkea opintokeskusten ja kansalais- ja työväenopistojen - välillä, minkä verran ja missä sisältöalueissa esiintyy päällekkäisyyttä; esim.: mikä erottaa toisistaan opintokeskuksen ja työväenopiston "Luovan itseilmaisun kurssille" osallistujan?

- edelliseen liittyen sivistysjärjestöjen opintotoimintaan osallistuvien koulutustaustaselvitys, jolloin mm. sen myytin tutkiminen, tavoittavatko opintokeskukset vähiten koulutetut ja lähellä työväenluokkaa olevat (vrt. Suomen raportti Unescon 4. aikuiskasvatuskonferenssille 1985).

- opintotoiminnan sisältövertailut vapaan sivistystyön eri muotojen kesken, erityisesti opintokeskusten ja kansalais-työväenopistojen välillä, mikä on tänään opintokeskusten rooli "yhteiskunnallisen opetuksen", 
antajina, miten "yhteiskunnallisen opetuksen" sisältö on muuttunut opintokeskuslain voimassaoloaikana (vrt. Aulis Alanen sivistysjärjestötutkimus), miten se on painottunut opintokerho-opiskelussa/lyhytkurssitoiminnassa; mitä kaikkea kansalaisja työväenopistojen "yhteiskunnallinen opetus" sisältää, minkätyyppisiin sisältöihin se painottuu jne.

- opintokerho ja sen käyttö sivistysjärjestöjen opintotoiminnassa vaatisi uutta tutkimusta, erityisesti opintokeskuslain aiheuttamien muutosten ja sen aseman muutosten kannalta; muutoinkaan aikuiskasvatustutkimes ei ole juuri paneutunut opintoryhmien sosiaalipsykologian tutkimiseen.

- tietotekniikan opetuksen järjestäminen vaatii tällä hetkellä runsaasti tutkimustietoa tuekseen - myös vapaan sivistystyön alueella. Tutkimusta tarvitaan erityisesti tietotekniikan opetussuunnitelmien, oppimateriaalien ja opettajankoulutuksen kehittämisen pohjaksi. Aikuiskasvatuksen tutkijat eivät saisi suhtautua tietotekniikan opetuksen järjestämiseen aikuisille jonkin- laisena muoti-ilmiönä, jonka tulee jäädä tutkijoiden kiinnostuksen ulkopuolelle. Päinvastoin: tietotekniikan parissa liikkuu kaiken aikaa monenlaisia kaupallisia yrittäjiä ja helppoheikkejä, jotka vaativat vastapainoksi suunnitellusti ja järkevästi järjestettyä tietotekniikan opetusta.

Lopuksi joitakin sanoja tutkimuksen ja kentän välisestä yhteistyöstä. Vapaan sivistystyön piirissä on viime vuosina voimistunut amatööritutkimus, mikä ilmenee sivistysjärjestöissä ns. tutkivien ja tuottavien opintokerhojen lisääntymisenä. Olisi tärkeää, että aikuiskasvatustutkimus kiinnostuisi tästä ilmiöstä ja olisi amatööritutkimuksen tukena; uskoisin hyödyn yhteistyöstä olevan molemminpuolista. Lisäksi toivoisin, että yliopistot ja ns. käytännön aikuiskasvatusjärjestöt ja -laitokset voisivat tiivistää yhteistyötään; se voisi olla mm. tärkeiksi koettujen aiheiden tarjoamista pro gradu-töiksi, opiskelijoiden harjoittelua aikuiskasvatuslaitoksissa, käytännön aikuiskasvatustyötä käsittelevien kurssien ja seminaarien järjestämisestä aikuiskasvatuksen opiskelijoille ja aikuiskasvatuksen tutkimusseminaarien jatkamista. 